\title{
Subtropical-Tropical Urban Tree Water Relations and Drought Stress Response Strategies
}

\author{
Roger Kjelgren, Daryl Joyce, and David Doley
}

\begin{abstract}
Understanding native habitats of species successful as subtropical and tropical urban trees yield insights into how to minimize urban tree water deficit stress experienced during monsoonal dry periods. Equatorial and montane wet forest species rarely subject to drought are generally absent in subtropical and tropical cities with pronounced monsoonal dry seasons. Species native to monsoonal dry forests appear to have wide environmental tolerances, and are successful as urban trees in many tropical cities. Monsoonal dry forest species have a tendency to be deep rooted to avoid drought, with leaf habits falling along an avoidance to tolerance spectrum. Dry deciduous species, typically found on more fertile soils, maximize growth during the monsoonal wet season with high photosynthesis and transpiration rates, then defoliate to avoid stress during the dry season. Evergreen tree species, typically found on less fertile soils, have a higher carbon investment in leaves that photosynthesize and transpire less year-round than do dry deciduous species. Dry deciduous tree species are more common urban trees than dry evergreen species explicitly due to more ornamental floral displays, but also implicitly due to their ability to adjust timing and duration of defoliation in response to drought. An empirical study of three tropical species exhibiting a range of leaf habits showed isohydric behavior that moderates transpiration and conserves soil water during drying. However, dry evergreen species may be less adaptable to tropical urban conditions of pronounced drought, intense heat, and limited rooting volumes than dry deciduous species with malleable leaf habit.

Key Words. Climate Change; Drought Deciduous; Drought Physiology; Dry Evergreen; Lagerstroemia loudonii; Pterocarpus indicus, Swietenia macrophylla; Urban Forestry; Water Stress; Wet Evergreen.
\end{abstract}

Urban trees are an increasingly important quality of life issue in tropical cities as economic growth swells their increasingly affluent urban populations (Nilsson 2005). The understanding and management of urban trees in tropical cities (including subtropical cities where cold does not seasonally limit growth), particularly the street tree population, is based on a modest body of scientific knowledge. Temperate (seasonal cold limiting growth) urban tree understanding and management does not necessarily translate well to tropical trees. Tropical trees are adapted to a wide range of rainfall conditions ranging from year-round rainfall to monsoonal climates, where heavy wet seasons vary in duration and periodicity in alternation with often-pronounced dry seasons.

Freestanding urban trees growing along streets, in street medians, or on private properties are a critical foundation for both a healthy human population and a healthy economy (Tzoulas et al. 2007). The UN World Health Organization recommends at least $9 \mathrm{~m}^{2}$ of urban greenspace per capita to mitigate undesirable environmental effects and to provide aesthetic benefits (Deloya 1993). Urban forests are particularly important to healthy cities in developing countries, which constitute some of the world's largest metropolitan areas. Greenspace and urban tree plantings become imperative where the rate of urbanization is greatest in developing countries, particularly in smaller cities of 500,000 people in Asia and Africa (UN-ESA 2003).

Tropical cities in developing countries have a diverse pool of potential tree species available from tropical forests (Jim and Liu 2001). The selection of those tree species best suited for tropical urban conditions depends upon matching above and belowground space (Jim 2001) and on matching urban climate to species from an appropriate tropical forest type. Selecting urban trees from an appropriate tropical forest type also depends upon where a tropical city falls along the seasonality gradient of rainfall distribution. This gradient ranges from aseasonal wet, with significant rainfall every month and dry periods rarely longer than a week to a monsoonal climate with alternating dry and wet seasons of varying length and periodicity. Generally, forest tree species in aseasonal wet climates can be described as wet evergreen, while those in monsoonal climates are either deciduous or dry evergreen. While not addressing the many nuances among tropical forest types, this generalization provides a functional conceptual framework for understanding tree adaptations to drought in tropical and subtropical cities.

Cities in equatorial wet climates, such as Singapore in Southeast Asia, logically use many trees from equatorial wet evergreen aseasonal forests. However, cities in wet equatorial climates also use drought-adapted trees from monsoonal climates (Tee and Wee 2001). This is similar in strategy to temperate cities using tree species from colder climates. Tropical monsoonal dry forest species are adapted to forest environments subject to several months of low rainfall (Miles et al. 2006). Tropical dry forest species either avoid drought with a deciduous leaf habit or tolerate drought with evergreen foliage (Santiago et al. 2004). When grown in a wet, aseasonal climate predominated by evergreen species, drought-deciduous species typically retain their leaves most of the year, sometimes shedding foliage briefly during short dry periods (Brodribb and Holbrook 2005). 
While monsoonal drought-adapted tree species can be used in an aseasonal wet evergreen climate, the reverse does not appear to be true. Street trees in Bangkok, Thailand, were dominated by deciduous species, mostly native to Southeast Asia but also from Africa and South America (Thaiutsa et al. 2008). This was due largely to deciduous species typically having more ornamental floral displays. Dry evergreen species were more common as large specimen trees, but most were older, often declining specimens found in protected urban locations (Thaiutsa et al. 2008). Similarly, Nagendra and Gopal (2010) reported that deciduous trees dominated the street-side tree population in Bangalore, India. Of the evergreen species, only one was ostensibly from a wet evergreen forest.

Understanding differences in ecological physiology between dry and wet tropical forest species can explain the relative distribution and abundance of deciduous and evergreen species in tropical cities, and inform how they can be managed for drought. Combined with insights into forest change from modeled projections under increased temperature scenarios and paleo-climate reconstructions, urban landscapers in tropical cities can potentially select appropriate deciduous and evergreen tropical species that are best adapted to future hotter and drier conditions. The purpose of this paper is to consider how an appreciation of monsoonal tree species adaptations to variable drought can inform sub/tropical urban tree understanding and management.

\section{TROPICAL FOREST TYPES AND ADAPTATION}

\section{Monsoonal Dry Forests}

The climate of most subtropical and tropical cities has one or several dry periods long enough that water stress and negative growth effects emerge if not understood and managed properly. Monsoonal dry forests are found within tropical latitudes where the dry season is long enough to cause routine soil water deficits despite episodic rainfall, while the wet season duration is sufficient to support a forest canopy. Because of the extended dry season, monsoonal species appear to be characteristically more deeply rooted than other forest types (Schenck and Jackson 2005), although coarse textured soil can sometimes create dry-deciduous islands in otherwise evergreen forests (Bohlman 2010). Dry forests are a significant ecosystem in the monsoonal tropics whose rich animal and plant biodiversity, particularly in understory environments with greater illumination, is under threat from a range of anthropogenic activities (Miles et al. 2006). The biodiversity of tropical dry forests yields many economically important timber and medicinal species (Johnson and Grivetti 2008) and is also a source of genetic diversity for breeding programs (Purushothaman et al. 2000).

Where soil nutrient levels are low, evergreen species are typically favored, sometimes mixed with deciduous species (Choat et al. 2005; Ishida et al. 2006). Dry evergreen forest species must tolerate intense solar radiation, heat, and drought during the dry season, and low light and high rainfall during the wet season (Graha et al. 2003). The relatively small leaves of dry evergreen forest species relative to deciduous species minimize interception of solar radiation and maximize convective and radiative cooling during the dry season (Pittman 1996). Evergreen species with lower leaf nitrogen concentrations, greater leaf longevity, and greater internal recirculation of nutrients have a lower investment in nitrogen per unit of photosynthetic machinery per year than do deciduous species (Doley 1982; Wright et al. 2002), but they must tolerate low leaf water potentials and survive desiccation (Pittman 1996; Brodribb et al. 2003) during the extended dry season. Dry evergreen forest species typically have lower stomatal conductance and photosynthetic rates than do deciduous species (Choat et al. 2005; Ishida et al. 2006) and a lower hydraulic conductance that limits stomatal conductance and lowers internal water potentials (Brodribb et al. 2003; Ishida et al. 2006).

Deciduous species in monsoonal dry forests have a tendency to occupy more nutrient rich soils, where fire can determine a particular forest subtype (Miles et al. 2006). Dry-deciduous species typically have high transpiration rates and hydraulic conductivities that maximize productivity during wet season foliation. This forest type then enters deciduous leaf senescence to defoliate at some point during the dry season (Choat et al. 2005; Ishida et al. 2006). Deciduous dry forest tree species, in fertile soil where the cost of nutrient loss is not limiting, exhibit a remarkable array of adaptations in response to extreme seasonal wetness and drought. Drought-deciduous species vary with respect to leaf longevity and length of dormancy in response to drought (Elliot et al. 2006) and in hydraulic properties. Some species may undergo xylem cavitation and defoliate in response to modest water stress at relatively less negative internal water potentials and then initiate refoliation with new xylem as rainfall increases the soil water content with onset of the wet monsoon season (Brodribb et al. 2002). Other species under mild water stress avoid cavitation entirely and maintain functional xylem while defoliated. This form of drought sensitivity minimizes soil water depletion, maximizes soil water content, and allows refoliation and sunlight capture before the onset of the wet season and subsequent increased competition for sunlight (Brodribb et al. 2003; Elliot et al. 2006). Some drought-deciduous species have high exchangeable trunk water storage capacity due to their wood anatomy, which facilitates the avoidance of low soil water potential effects by such species (Borchert and Pockman 2005).

Hydraulic signaling appears, however, to be an incomplete explanation for drought-induced dormancy. Changes in hydraulic properties do not correlate to gas exchange reduction prior to senescence in many tropical deciduous species (Brodribb et al. 2002; Brodribb et al. 2003). The speed of signal transfer and the distances over which the signals must be transported in trees would not result in timely stomatal responses to diurnal variations in environmental conditions. Leaf size and heating may provide a possible alternative explanation for drought-induced dormancy in these species. A number of drought-deciduous species have relatively large leaves, such as are rarely found in full sun habitats [e.g., Tectona grandis L. f. (teak) and a number of dipterocarp species (Sales-Come and Holscher 2010)]. Large leaves can be maintained only if high transpiration rates facilitate evaporative cooling and maintain photosynthetically optimum leaf temperatures, a characteristic consistent with high stomatal conductance and wide xylem vessels capable of high hydraulic conductance as are found in drought-deciduous species (Choat et al. 2005; Ishida et al. 2006).

High transpiration rates, particularly in species with large leaves, suggest a possible defoliation signal in drought-deciduous species. These species appear to have stomata sensitive to leaf-air vapor pressure difference (LAVPD) (Ishida et al. 2006). Mild, dry season water stress may trigger a rapid and large drop in stomatal conductance in response to a small change in soil water potential, with minimal cavitation and negligible loss of 
xylem function (Brodribb et al. 2003). A large decrease in stomatal conductance somewhat decoupled from water potential can be explained by a feed-forward process mediated by LAVPD and enhanced by large leaf size, where a small reduction in conductance from soil drying reduces transpirational cooling. Reduced transpirational cooling would increase leaf temperature and LAVPD, which, in turn, would push conductance even lower and LAVPD higher in a feed-forward loop. Buildup of leaf-level abscisic acid (ABA) has been linked to stomatal closure in trees, not only during soil drying (Bauerle et al. 2003), but also in very dry air conditions that causes high LAVPD (Bauerle et al. 2004). Thus, a large-leafed species could reach rapid stomatal closure from small changes in soil drying and decreased internal water potential due to leaf heating that, in turn, triggers ABA buildup to the point of inducing leaf senescence.

\section{Wet Evergreen}

Equatorial wet evergreen forests largely, but not exclusively, fall within +/- 10 degrees latitude of the equator in three global regions. These regions are the Amazon basin in western South America, the Congo in central Africa, and in Southeast Asia from Malaysia to eastern New Guinea (Kottek et al. 2006). A simple characterization of these forests is aseasonal annual precipitation of over $2,000 \mathrm{~mm}$, with each month receiving at least $60 \mathrm{~mm}$ of rainfall (Kottek et al. 2006) and resulting in no distinct dry season.

Since water is not limiting, wet evergreen forest species compete for more limited nitrogen and light (Graha et al. 2003). Wet evergreen species typically have shallower root systems than do monsoonal dry forest species (Schenk and Jackson 2005). Shallower roots are more effective at scavenging scarce nitrogen from forest-floor dry matter decomposition (Santiago et al. 2004). With less biomass needed for deep root production, wet evergreen species invest more biomass in leaves (Santiago et al. 2004) that are long lived and more efficient at nitrogen use (Wright et al. 2002). Light is particularly limiting for seedling recruitment. Whole plant shade tolerance is a key adaptation that allows seedlings to persist in the understory until a gap allows enough light for vigorous growth (Baltzer and Thomas 2007).

As a trade-off for adaptation to light and nitrogen scavenging, aseasonal climate wet evergreen species are less tolerant of soil and atmospheric water deficits (Brenes-Arguedas et al. 2008). That is, wet evergreen species are less drought tolerant at the physiological level than species found in monsoonal dry habitats (Baltzer et al. 2007), with less desiccation-tolerant leaves (Baltzer et al. 2008) and xylem hydraulic properties (Baltzer et al. 2009), particularly at the seedling stage (Kursar et al. 2009). The wet evergreen members of co-generic species pairs have higher aboveground growth rates than do related species from monsoonal habitats with distinct dry seasons (Baltzer et al. 2007). Wet evergreen species are also not tolerant to atmospheric water deficits. Adapted to year-round wet and humid conditions, upper canopy tree species in aseasonal wet forests maintain high photosynthesis rates at low levels of vapor deficits, but exhibit steep stomatal closure and reduced photosynthesis as vapor deficits increase (Cunningham 2006).

Tropical wet evergreen forest species are essentially specialists attuned to a relatively specific set of environmental conditions (Woodruff 2010), where drought is absent (Baltzer et al. 2007). Wet evergreen forests also function within a nar- row temperature range (Woodruff 2010), thus physiological and morphological mechanisms to survive greater water and temperature ranges are not evident (Baltzer et al. 2007; Baltzer et al. 2008; Baltzer et al. 2009; Kursar et al. 2009).

A subset of wet evergreen tropical forest habitats includes montane forests. These forests exist in cooler, higher elevation climates than do lowland wet evergreen forests in a broader latitudinal range within the tropics (Bubb et al. 2004). Higher elevation translates to cooler temperatures and lower vapor deficits and evapotranspiration, resulting in a more favorable water balance (Tanaka et al. 2003). Montane forests may be subject to monsoonal dry periods. Evapotranspiration peaks during the dry season, and the general presence of deep soils suggests that water stress is not a decisive factor in characterizing this forest type (Tanaka at al. 2008). Likely due to their temperature limits and limited adaptability to water stress (Foster 2001), montane species are not typically found in urban tree populations in either monsoonal or wet equatorial cities. In general, wet evergreen forest species are not typically used in monsoonal sub/tropical cities because they are, in essence, specialists (Woodruff 2010) adapted to nutrient and light limited habitats, and unlikely to tolerate soil and atmospheric water deficits during monsoonal dry periods (Kjelgren et al. 2011).

\section{WATER STRESS - TROPICAL URBAN TREES}

Urban heat island effects are characteristic of all cities and arise from increased sensible and re-radiated heat from impervious surfaces (Rizwan et al. 2008). In tropical and subtropical regions, cities with pronounced monsoonal dry seasons may experience particularly intense heat islands (Roth 2007). While vegetation can mitigate against heat islands (Roth 2007), urban vegetation in tropical cities will be affected nonetheless by elevated temperatures from climate change, in general, and through attendant increased heat loading from asphalt (Kjelgren and Montague 1998) and other non-transpirating surfaces (Montague and Kjelgren 2004). In particular, the crowns of freestanding isolated street trees will be subject to higher heat loading (Kjelgren and Clark 1993). The degree of heating depends on sensible heat dissipation as a function of leaf size (Leuzinger et al. 2010) and stomatal conductance, which determines the degree of coupling of the leaf with the atmosphere (Jarvis and McNaughton 1986). Temperature interacts with limited soil water due to confined root zones, due to either limited volume or depth (Bondarenko 2009), to impose water stress on urban trees (Close et al. 1996).

Studies of street tree populations in Bangkok, Thailand (Thaiutsa et al. 2008), and Bangalore, India (Nagendra and Gopal 2010), suggest that dry-deciduous species are more tolerant of monsoonal dry urban climates. Both of these cities have pronounced monsoonal climates with a four- to six-month dry season and a majority of deciduous species in their street tree populations. In each city, evergreen species comprised only one-third of the top 15 most commonly used street tree species, and those evergreen species used as street trees were largely from drier and harsher habitats than most species from wet equatorial forests (Kjelgren et al. 2011).

The use of deciduous tree species in tropical cities in Asia appears to be the result of informal selection processes. Thaiutsa et al. (2008) also surveyed older, large specimen trees (growing on private property not along a city street) in Bang- 
kok that were much older than the street tree population. These specimen trees were dominated by evergreen species from dry evergreen forests, particularly in the genus Ficus, rather than by deciduous species. However, only four of the most common specimen trees were also common as street streets, and two of these four were deciduous. Limited crossover between old specimen and street tree species suggests that evergreen species even from dry habitats did not perform as well as deciduous species in urban areas, resulting in proportionally greater adoption of deciduous species as street trees. The apparent heat tolerance limitation of evergreen species is consistent with Woodruff's (2010) observation that the current distributions of evergreen tropical forests, certainly from aseasonal, but possibly also seasonal habitats (Trisurat et al. 2009), reflect their temperature limits. Thus, the circumstantial evidence suggests that evergreen tropical tree species are less suited to higher urban heat island temperatures in subtropical and tropical cities.

\section{Empirical Studies}

Recent studies illustrate the differences in adaption among sub/ tropical evergreen versus deciduous species used as urban street trees. Kjelgren et al. (2008) investigated water use of three tropical tree species varying in leaf habit and commonly used in Bangkok's streetside population. In plotting the frequency distribution of water use rates expressed as the ratio of daily water use $\left(\mathrm{mm} \mathrm{day}^{-1}\right)$ to local reference evapotranspiration (the plant factor, $\mathrm{Kp}$ ), the dry deciduous species Lagerstroemia loudonii (closely related to Star of India, Lagerstroemia speciosa) had the highest use (Figure 1, modified from Kjelgren et al. 2008). Consistent with reports that dry deciduous species have hydraulic architecture (Choat et al. 2005) supporting higher stomatal conductance (Ishida et al. 2006), L. loudonii Kp values reached a maximum of between $40 \%-50 \%$ of reference evapotranspiration $\left(\mathrm{ET}_{\mathrm{o}}\right)$. Higher stomatal conductance and transpiration

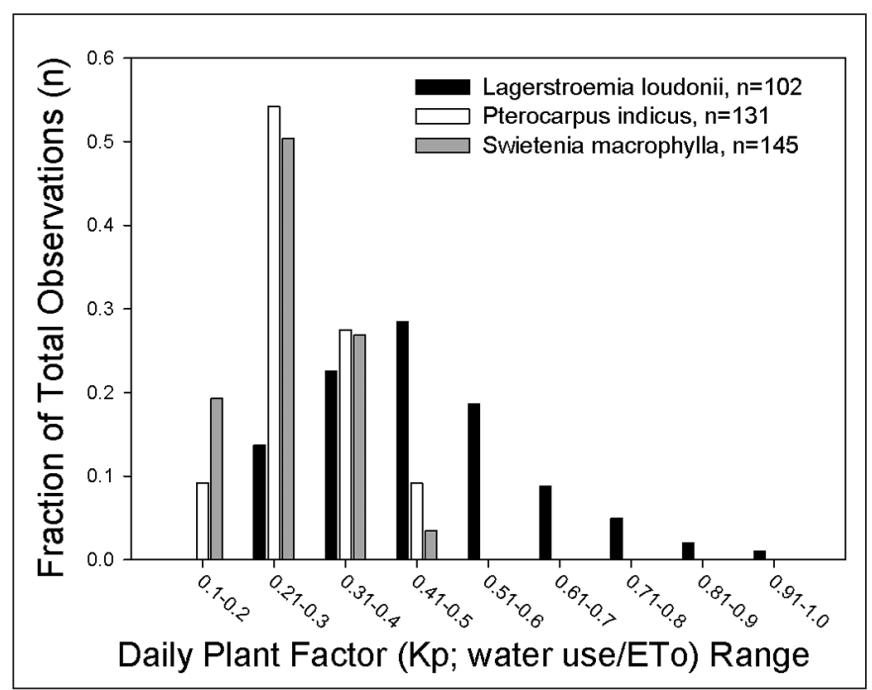

Figure 1. Monsoonal dry season (January-April) water use normalized to depth units ( $\mathrm{mm} /$ day) for container grown Pterocarpus indicus, Swietenia macrophylla, and Lagerstroemia loudonii, three sub/tropical trees species common in Bangkok, Thailand's streetside population, where $\mathrm{n}$ is the number of daily observations over six replicates per species (modified from Kjelgren et al. 2009). rates for sub/tropical dry deciduous species would be consistent with high carbon gain over the monsoonal wet period, in contrast to evergreen species that can photosynthesize year round.

By contrast, the $\mathrm{Kp}$ of both Pterocarpus indicus (angsana) and Swietenia macrophylla (mahogany) was lower at 20\%-30\% of $\mathrm{ET}_{\mathrm{o}}$. Swietenia macrophylla is a dry evergreen species from monsoonal regions in South America. Its lower transpiration rate would slowly deplete soil water during the monsoonal dry period and allow extended carbon gain. $P$. indicus can be facultative deciduous when conditions become dry, but is otherwise evergreen. $P$. indicus is found along sandy seashores, suggesting tolerance to drought and salt under stressful conditions. However, it can aggressively grow and expand habitat under more favorable conditions. Notable in comparing these three species is that the distribution of $\mathrm{Kp}$ values is much broader for L. loudonii, approaching ET on occasion. High stomatal conductances imply greater sensitivity of transpiration to environmental factors that can affect stomatal opening, such as vapor deficits and wind.

When subjected to drying conditions, all three species exhibited a similar response to water stress (unpublished data). All of the trees were growing in containers when subjected to substrate drying. The stomatal conductance quickly declined in all three species, moderating internal water potential. Since isolated trees are well ventilated (Jarvis and Morison 1981), stomatal conductance to water vapor is closely coupled to the atmosphere, exerting close to a direct 1:1 relationship between incremental stomatal closure and transpiration rate (Jarvis 1985). Stomatal closure at incipient substrate drying reduces evaporative strain on internal water potential, an isohydric response to water stress that slows the depletion of root zone water (Schultz 2003). All three species maintained an isohydric response as stomatal conductance declined to approximately $30 \%$ of well-watered levels. However, at this point, $P$. indicus isohydric control failed and internal water potential declined quickly as conductance fell to about $10 \%$ of well-watered levels. Total leaf area of $P$. indicus was substantially greater than the other two species, such that the obvious explanation is that it depleted substrate water content to what was, in effect, the permanent wilting point.

The studies in Bangkok's monsoonal climate indicate that three commonly used sub/tropical tree species exhibit an isohydric water stress response strategy, similar to many temperate woody species (Shultz 2003). This isohydric response favors lower stomatal aperture, transpiration, and possibly photosynthesis in exchange for slower depletion of root zone waterin essence, a "save it for a rainy day" strategy (Kjelgren et al. 2009). Combined with the deep rooting common in monsoonal forest species (Schenk and Jackson 2005), and traits that either favor drought avoidance or drought tolerance through leaf morphological characteristics (e.g., smaller, denser leaves; Wright et al. 2002), monsoonal dry forest species that are either deciduous or evergreen appear to be well-equipped to tolerate drought as street trees in subtropical and tropical cities.

Acknowledgments. Thanks to the U.S. State Department and Council for International Exchange of Scholars

Fulbright Fellowship program and the University of Queensland for their support that led to this publication. 


\section{LITERATURE CITED}

Baltzer, J.L., and S.C. Thomas. 2007. Determinants of whole-plant light requirements in Bornean rain forest tree saplings. Journal of Ecology 95:1208-1221.

Baltzer, J.L., D.M. Gregoire, S. Bunyavejchewin, N.S.M. Noor, and S.J. Davies. 2009. Coordination of foliar and wood anatomical traits contributes to tropical tree distributions and productivity along the Malay-Thai Peninsula. American Journal of Botany 96:2214-2223.

Baltzer, J.L., S.J. Davies, A.R. Kassim, and J.V. LaFrankie. 2007. Geographical distributions in tropical trees: Can geographical range predict performance and habitat association in co-occurring tree species? Journal of Biogeography 34:916-926.

Baltzer, J.L., S.J. Davies, S. Bunyavejchewin, and N.S.M. Noor. 2008. The role of desiccation tolerance in determining tree species distributions along the Malay-Thai Peninsula. Functional Ecology 22: 221-231.

Bauerle, W.L., T.H. Whitlow, T.L. Setter, and F.M. Vermeylen. 2004. Abscisic acid synthesis in Acer rubrum L. leaves a vapour-pressuredeficit-mediated response. Journal of the American Society for Horticultural Science 129:182-187.

Bauerle, W.L., T.H. Whitlow, T.L. Setter, T.L. Bauerle, and F.M. Vermeylen. 2003. Ecophysiology of Acer rubrum seedlings from contrasting hydrologic habitats: Growth, gas exchange, tissue water relations, abscisic acid and carbon isotope discrimination. Tree Physiology 23:841-850

Bohlman, S. 2010. Landscape patterns and environmental controls of deciduousness in forests of central Panama. Global Ecology and Biogeography 19:376-385.

Bondarenko, V.V. 2009. Soil water regime and evapotranspiration of sites with trees and lawn in Moscow. Ph.D. dissertation, Univ. of Wageningen, Wageningen, Netherlands. $171 \mathrm{pp}$.

Borchert, R., and W.T. Pockman. 2005. Water storage capacitance and xylem tension in isolated branches of temperate and tropical trees. Tree Physiology 25:457-466.

Brenes-Arguedas, T., M. Rios, G. Rivas-Torres, C. Blundo, P.D. Coley, and T.A. Kursar. 2008. The effect of soil on the growth performance of tropical species with contrasting distributions. Oikos 117:1453-1460.

Brodribb, T.J, and N.M. Holbrook. 2005. Leaf physiology does not predict leaf habit: Examples from tropical dry forest. Trees-Structure and Function 19:290-295.

Brodribb, T.J., N.M. Holbrook, and M.V. Guteirrez. 2002. Hydraulic photosynthetic coordination in seasonally dry tropical forest trees. Plant, Cell and Environment 25:1435-1444.

Brodribb, T.J., N.M. Holbrook, E.J. Edwards, and M.V. Guteirrez. 2003. Relation between stomatal closure, leaf turgor and xylem vulnerability in eight tropical dry forest trees. Plant, Cell and Environment 26:443-450

Bubb, P., I. May, L. Miles, and J. Sayer. 2004. Cloud forest agenda. United Nations Environment Programme World Conservation Monitoring Centre. Cambridge, UK. 32 pp.

Choat, B., M.C. Ball, J.G. Luly, and J.A. Holtum. 2005. Hydraulic architecture of deciduous and evergreen dry rainforest tree species in north-eastern Australia. Trees 19:305-311.

Close, R.E., J.J. Kielbaso, P.V. Nguyen, and R.E. Schutzki. 1996. Urban vs. natural sugar maple growth: II. Water relations. Journal of Arboriculture 22:187-192.

Cunningham, S.C. 2006. Effects of vapour pressure deficit on growth of temperate and tropical evergreen rainforest trees of Australia. Acta Oecologica 30:399-406.

Deloya, M.C. 1993. Urban forestry activities in Mexico. Unasylva $173: 28-32$.
Doley, D. 1982. Photosynthetic productivity of forest canopies in relation to solar radiation and nitrogen cycling. Australian Forest Research 12:245-261.

Elliot, S., P.J. Baker, and R. Borchert. 2006. Leaf flushing during the dry season: The paradox of Asian monsoon forests. Global Ecology and Biogeography 15:248-257.

Foster, P. 2001. The potential negative impacts of global climate change on tropical montane cloud forests. Earth-Science Reviews 55:73-106.

Graha, E.A., S.S. Mulkey, K. Kitajima, N.G. Phillips, and S.J. Wright. 2003. Cloud cover limits net $\mathrm{CO}_{2}$ uptake and growth of a rainforest tree during tropical rainy seasons. Proceedings of the National Academy of Sciences 100:572-576.

Ishida, A., S. Diloksumpun, P. Ladpala, D. Staporn, S. Panuthai, M. Gamo, K. Yazaki, M. Ishizuka, and L. Puangchit. 2006. Contrasting seasonal leaf habits of canopy trees between tropical dry-deciduous and evergreen forests in Thailand. Tree Physiology 26:643-656.

Jarvis, P. 1985. Coupling of transpiration to the atmosphere in horticultural crops: The Omega Factor. Acta Horticulturae (ISHS) 171:187-206.

Jarvis, P., and J. Morison. 1981. The control of transpiration and photosynthesis by the stomata, pp. 247-279. In: P. Jarvis and T. Mansfield (Eds.). Stomatal Physiology. Cambridge University Press, Cambridge, UK.

Jarvis, P., and K. McNaughton. 1986. Stomatal control of transpiration: Scaling up from leaf to region. Advances in Ecological Research 15:1-49.

Jim, C.Y, and H.T. Liu. 2001. Patterns and dynamics of urban forests in relation to land use and development history in Guangzhou City, China. Geographical Journal 167:358-375.

Jim, C.Y. 2001. Managing urban trees and their soil envelopes in a contiguously developed city environment. Environmental Management 28:819-832.

Johnson, N., and L.E. Grivetti. 2008. Environmental change in northern Thailand: Impact on wild edible plant availability. Ecology of Food and Nutrition 41:373-399.

Kjelgren, R., and J. Clark. 1993. Growth and water relations of Liquidambar styraciflua $\mathrm{L}$. in an urban park and plaza. Trees-Structure and Function 7:195-201.

Kjelgren, R., and T. Montague. 1998. Urban tree transpiration over turf and asphalt surfaces. Atmospheric Environment 32:35-41.

Kjelgren, R., L. Puangchit, C. Sriladda, and M. Someechai. 2008. Water use of four street tree species in Bangkok, Thailand. Acta Horticulturae 792:405-409.

Kjelgren, R., L. Wang, and D. Joyce. 2009. Water deficit stress responses of three herbaceous native Australian ornamental species. HortScience 44:1358-1365.

Kjelgren, R., Y. Trisurat, N. Baguinon, L. Puangchit, and P.Y. Tan. 2011. Tropical street trees and climate uncertainty in Southeast Asia. HortScience 46:167-142.

Kottek, M., J. Grieser, C. Beck, B. Rudolf, and F. Rubel. 2006. World Map of the Köppen-Geiger climate classification updated. Meteorologische Zeitschrift 15:259-263.

Kursar, T.A., B.M.J. Engelbrecht, A. Burke, M.T. Tyree, B. El Omari, and J.P. Giraldo. 2009. Tolerance to low leaf water status of tropical tree seedlings is related to drought performance and distribution. Functional Ecology 23:93-102.

Leuzinger, S., R. Vogt, and C. Korner. 2010. Tree surface temperature in an urban environment. Agricultural and Forest Meteorology 150:56-62.

Miles, L., A.C. Newton, R.S. DeFries, C. Ravilious, I. May, S. Blyth, V. Kapos, and J. Gordon. 2006. A global overview of the conservation status of tropical dry forests. Journal of Biogeography 33:491-505. 
Montague, T., and R. Kjelgren. 2004. Energy balance of six common landscape surfaces and the influence of surface properties on gas exchange of four containerized tree species. Scientia Horticulturae 100:229-249.

Nagendra, H., and D. Gopal. 2010. Street trees in Bangalore: Density, diversity, composition and distribution. Urban Forestry \& Urban Greening 9:129-137.

Nilsson, K. 2005. Urban forestry as a vehicle for healthy and sustainable development. Chinese Forestry Science and Technology 4:1-14.

Pittman, J. 1996. Ecophysiology of tropical dry evergreen forests, Thailand: Measured and modelled stomatal conductance of Hopeaferrea, a dominant canopy emergent. Journal of Applied Ecology 33:1366-1378.

Purushothaman, S., S. Viswanath, and C. Kunhikannan. 2000. Economic valuation of extractive conservation in a tropical deciduous forest in Madhya Pradesh, India. Tropical Ecology 41:61-72.

Rizwan, A.M, Y.C.L. Dennis, and C.H. Liu. 2008. A review on the generation, determination and mitigation of urban heat island. Journal of Environmental Sciences 20:120-128.

Roth, M. 2007. Review of urban climate research in (sub)tropical regions. International Journal of Climatology 27:1859-1873.

Sales-Come, R., and D. Holscher. 2010. Variability and grouping of leaf traits in multi-species reforestation (Leyte, Philippines). Forest Ecology and Management 260:846-855.

Santiago, L.S., K. Kitajima, S.J. Wright, and S.S. Mulkey. 2004. Coordinated changes in photosynthesis, water relations and leaf nutritional traits of canopy trees along a precipitation gradient in lowland tropical forest. Oecologia 139:495-502.

Schenk, H.J., and R.B. Jackson. 2005. Mapping the global distribution of deep roots in relation to climate and soil characteristics. Geoderma 126:129-140.

Schultz, H.R. 2003. Differences in hydraulic architecture account for near-isohydric and anisohydric behaviour of two field-grown Vitis vinifera L. cultivars during drought. Plant, Cell and Environment 26:1393-1405.

Tanaka, K., H. Takizawa, N. Tanaka, I. Kosaka, N. Yoshifuji, C. Tantasirin, S. Piman, M. Suzuki, and N. Tangtha. 2003. Transpiration peak over a hill evergreen forest in northern Thailand in the late dry season: Assessing the seasonal changes in evapotranspiration using a multilayer model. Journal of Geophysical Research 108:4-1 to 4-15.

Tanaka, N., T. Kume, N. Yoshifuji, K. Tanaka, H. Takizawa, K Shiraki, C. Tantasirin, N. Tangtham, and M. Suzuki. 2008. A review of evapotranspiration estimates from tropical forests in Thailand and adjacent regions. Agricultural and Forest Meteorology 148:807-819.
Tee, W.S., and L.M. Wee. 2001. Trees of our garden city: A guide to the common trees of Singapore. National Parks Board, Singapore. Singapore, Malaysia. 21 pp.

Thaiutsa, B., L. Puangchit, R. Kjelgren, and W. Arunpraparut. 2008. Urban green space, street tree and heritage large tree assessment in Bangkok, Thailand. Urban Forestry and Urban Greening 7:219-229.

Trisurat, Y., R. Alkemade, and E. Arets. 2009. Projecting forest tree distributions and adaptation to climate change in northern Thailand. Journal of Ecology and Natural Environment 1:55-63.

Tzoulas, K., K. Korpela, S. Venn, V. Yli-Pelkonen, A. Kazmierczak, J. Niemela, and P. James. 2007. Promoting ecosystem and human health in urban areas using green infrastructure: A literature review. Landscape and Urban Planning 81:167-178.

United Nations Dept. Economic and Social Affairs (UN-ESA). 2003. Long range population projections. In: Proc. of the Technical Working Group on Long-Range Population Projects. UN-ESA, New York, New York, U.S.

Woodruff, D.S. 2010. Biogeography and conservation in Southeast Asia: How 2.7 million years of repeated environmental fluctuations affect today's patterns and the future of the remaining refugial-phase biodiversity. Biodiversity and Conservation 19:919-941.

Wright, I.J., M. Westoby, and P.B. Reich. 2002. Convergence towards higher leaf mass per area in dry and nutrient-poor habitats has different consequences for leaf life span. Journal of Ecology 90:534-543.

Roger Kjelgren (corresponding author)

Department of Plants, Soils and Climate

Utah State University

4820 Old Main Hill

Logan, Utah 84322-4820, U.S.

roger.kjelgren@usu.edu

Daryl Joyce

School of Agriculture \& Food Sciences

University of Queensland, Gatton Qld.

Horticulture \& Forestry Science, Department of Employment, Economic Development \& Innovation

Dutton Park Qld.

Australia

David Doley

Centre for Mined Land Rehabilitation

University of Queensland, St Lucia Qld.

Australia 
Zusammenfassung. Ein Verstehen der natürlichen Habitate von Baumarten, die erfolgreich als tropische und subtropische Arten im urbanen Raum leben, führt zu der Einsicht, wie der urbane Wassermangelstress während der Trockenperioden im Monsun minimiert werden kann. Äquatoriale und montane Regenwaldarten, die selten Trockenheit erleben, sind in subtropischen und tropischen Städten mit monsunaler Trockenheit selten zu finden. Endemische Arten aus monsunalen Trockenwäldern hingegen scheinen eine breite Toleranz zu haben und sind in vielen tropischen Städten erfolgreich am Standort etabliert. Die Trockenwald-Baumarten haben die Tendenz, tief zu wurzeln um Trockenheit $\mathrm{zu}$ vermeiden und lassen innerhalb ihres Toleranzspektrums auch mal die Blätter fallen. Trockene, sommergrüne Arten, die typischer Weise auf mehr fruchtbaren Böden gefunden werden, maximieren ihr Wachstum während der monsunalen Regenperioden mit hoher Photosynthese und Transpirationsrate, und lassen dann während der Trockenzeit die Blätter fallen. Immergrüne Baumarten, die typischerweise auf weniger fruchtbaren Böden gedeihen, haben einen höheren Kohlenstoffanteil in den Blättern, die weniger photosynthetisieren und transpirieren als sommergrüne Arten. Sommergrüne, Trockenheitstolerante Arten sind häufiger als immergrüne, Trockenheitstolerante Arten in den Städten zu finden, insbesondere wegen der größeren Blütenpracht, aber auch explizit wegen ihrer Eigenschaft, ihren Blattfall und die Dauer dessen mit den Trockenperioden zu koordinieren. Eine empirische Studie an drei tropischen Baumarten, die eine Bandbreite von Blatteigenschaften aufweisen, zeigten ein isohydrisches Verhalten, welches die Transpiration mildert und das Bodenwasser während der Trockenheit konserviert. Dennoch können immergrüne Arten weniger Anpassung an die tropischen urbanen Bedingungen von ausgeprägter Trockenheit, intensiver Hitze und begrenztem Wurzelraum zeigen als die sommergrünen Arten mit den anpassungsfähigen Blatteigenschaften.
Resumen. El entendimiento de los hábitats de especies nativas exitosas como árboles urbanos subtropicales y tropicales da pistas sobre cómo minimizar el estrés del déficit de agua urbana para el árbol, experimentado durante los períodos secos monzónicos. Las especies de regiones húmedas ecuatoriales y de bosques montanos rara vez están sometidas a la sequía y están generalmente ausentes en las ciudades subtropicales y tropicales con estaciones monzónicas marcadamente secas. Las especies nativas de los bosques secos monzónicos parecen tener amplias tolerancias ambientales, y tienen éxito como árboles urbanos de muchas ciudades tropicales. Las especies monzónicas de bosque seco tienen una tendencia a estar muy arraigadas para evitar la sequía, con hábitos de hoja caediza a lo largo de un espectro para lograr la tolerancia. Las especies de hojas caducas, que suelen encontrarse en suelos más fértiles, maximizan el crecimiento durante la temporada del monzón húmedo con alta fotosíntesis y transpiración, entonces se defolian para evitar el estrés durante la estación seca. Las especies de árboles de hoja perenne, que suelen encontrarse en suelos menos fértiles, tienen una inversión de carbono más altos en las hojas en la fotosíntesis y transpiran menos el año que lo que hacen las especies de hojas caducas. Las especies de hoja caduca son árboles urbanos más comunes que las especies siempre verdes, debido a arreglos florales más ornamentales, pero también implícitamente debido a su capacidad para ajustar el tiempo y la duración de la defoliación en respuesta a la sequía. Un estudio empírico de tres especies tropicales que presentan una serie de hábitos foliares mostró un comportamiento isohídrico para la transpiración moderados, conservando la humedad del suelo durante la sequía. Sin embargo, las especies perennes pueden ser menos adaptables a las condiciones urbanas tropicales de sequía pronunciada, calor intenso, y los limitados volúmenes de enraizamiento que las especies de hojas caducas con hoja de hábito maleable. 